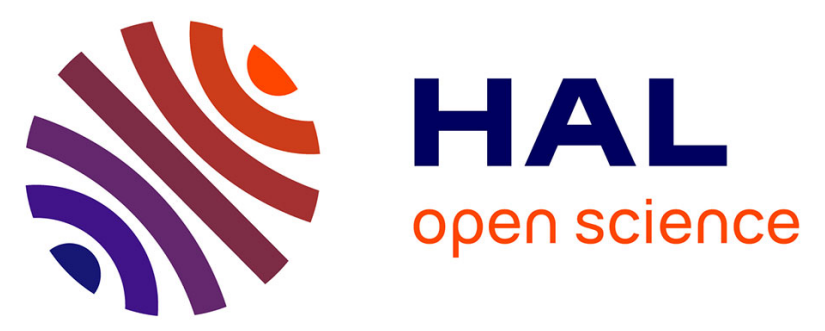

\title{
Relationships between sensorial characteristics and microbial dynamics in "Registered Designation of Origie' Salers cheese
}

Frédérique Duthoit, Cecile C. Callon, Laurent Tessier, Marie-Christine M.-C. Montel

\section{To cite this version:}

Frédérique Duthoit, Cecile C. Callon, Laurent Tessier, Marie-Christine M.-C. Montel. Relationships between sensorial characteristics and microbial dynamics in "Registered Designation of Origie' Salers cheese. International Journal of Food Microbiology, 2005, 103 (3), pp.259-270. 10.1016/j.ijfoodmicro.2004.11.040 . hal-02681975

\section{HAL Id: hal-02681975 https://hal.inrae.fr/hal-02681975}

Submitted on 1 Jun 2020

HAL is a multi-disciplinary open access archive for the deposit and dissemination of scientific research documents, whether they are published or not. The documents may come from teaching and research institutions in France or abroad, or from public or private research centers.
L'archive ouverte pluridisciplinaire HAL, est destinée au dépôt et à la diffusion de documents scientifiques de niveau recherche, publiés ou non, émanant des établissements d'enseignement et de recherche français ou étrangers, des laboratoires publics ou privés. 


\title{
Relationships between sensorial characteristics and microbial dynamics in "Registered Designation of Origin" Salers cheese
}

\author{
Frédérique Duthoit $^{\mathrm{a}}$, Cécile Callon ${ }^{\mathrm{a}}$, Laurent Tessier ${ }^{\mathrm{b}}$, Marie-Christine Montel ${ }^{\mathrm{a}, *}$ \\ ${ }^{a}$ Unité de Recherches Fromagères, INRA, 36 rue de Salers, 15000 Aurillac, France \\ ${ }^{\mathrm{b}}$ Station de Recherches en Technologie et Analyses Laitières, INRA, Place du champ de foire, 39801 Poligny cedex, France
}

Received 4 September 2003; received in revised form 2 July 2004; accepted 29 November 2004

\begin{abstract}
Raw milk cheeses show a wide diversity of sensorial characteristics, largely determined by the microflora of raw milk. Microbial dynamics in Registered Designation of Origin (R.D.O.) Salers cheese was assessed by DNA and RNA SSCP analysis on nine cheeses. These cheeses showed considerable diversity both in microbial dynamics and sensorial characteristics. Relationships between the sensorial characteristics and the microbial dynamics were studied. A global consideration of bacterial dynamics demonstrated that other bacteria than lactic acid bacteria can play a role in the elaboration of sensorial characteristics. Indeed, high CG\% Gram-positive bacteria can be involved. DNA data, as well as RNA data, appeared relevant to attempts to explain sensorial variance. Correlations between sensorial and microbial data were rather complex. Several microbial variables for DNA and RNA analyses, noted at different times of analysis, were correlated to each sensory variable. A global view of cheese microbial community proved to be insufficient in explaining the diversity of the sensorial qualities of R.D.O. Salers cheese.
\end{abstract}

(C) 2005 Elsevier B.V. All rights reserved.

Keywords: Cheese; Sensorial characteristics; SSCP; Microbial dynamics

\section{Introduction}

Registered Designation of Origin (R.D.O.) cheeses manufactured with raw milk are often characterized by a wide variety of tastes and textures that can be described by sensory analysis (Lavanchy et al., 1993; Bérodier et al., 1997). The sensory properties of

\footnotetext{
* Corresponding author. Tel.: +33471456410; fax: +3347145 6413.

E-mail address: cmontel@clermont.inra.fr (M.-C. Montel).
}

cheeses are determined to a great extent by glycolysis, proteolysis, including amino acid degradation, lipolysis, and fatty acid oxidation during ripening. These catabolytic activities are caused by enzymes from the milk, the rennet, but more generally from the microflora.

The role of raw milk microflora was highlighted by comparing the sensorial characteristics of cheese made from raw, pasteurized or microfiltered milk (Beuvier et al., 1997; Buchin et al., 1998). It was found that the flavor intensity score was higher for raw milk cheeses 
than for pasteurized milk cheeses. Pasteurized milk cheeses were more "lactic "and "fruity "compared to raw milk cheeses that were more "spiced", "pungent", "animal", "rancid", "bitter "(Buchin et al., 1998). The addition of a microfiltration retentate of raw milk in pasteurized milk restored some of the sensorial qualities of raw milk cheeses (Beuvier et al., 1997).

The effect of specific strains on the sensorial characteristics of cheeses had also been investigated by manufacturing cheeses with an adjunct culture in the milk. Adding Enterococcus faecium to Feta (Sarantinopoulos et al., 2002), Enterococcus faecalis to Cebreiro cheese (Centeno et al., 1999), or Lactobacillus strains to Arzua-Ulloa (Menendez et al., 2000) enhanced the desirable characteristics of these cheeses. Relationships between volatile compounds and aroma descriptors were established (Ben Lawlor et al., 2001; Rychlik and Bosset, 2001; Curioni and Bosset, 2002). Cheese flavor and texture attributes are the result of complex interactions between specific volatile and nonvolatile compounds and characteristics of the cheese matrix.

The relationships between microbial dynamics in raw milk cheeses and taste, texture and flavor have scarcely been studied at all. Most of the literature deals with studies concerning the identification, biochemical characterization and aromatic properties of isolates (Ayad et al., 1999; Spinnler et al., 2001). This kind of approach is not well suited for cheeses with complex microbial community, such as raw milk cheeses. Due to the complexity of raw milk cheese microflora, it may be better to obtain a global view of the dynamics of the microbial community. Molecular, culture-independent methods such as Denaturing Gradient Gel Electrophoresis or Temperature Gradient Gel Electrophoresis (DGGE or TGGE) (Muyzer and Smalla, 1998), Terminal Restriction Fragment Length Polymorphism (T-RFLP) (Liu et al., 1997) or Single-Strand Conformation Polymorphism (SSCP) (Lee et al., 1996) have been developed. These techniques have been applied to different food products. Microbial dynamics have been monitored during malt whisky fermentation (van Beek and Priest, 2002), during the fermentation of Italian sausages (Cocolin et al., 2001), traditional cassava starch (Ampe et al., 2001) or Ragusano cheese (Randazzo et al., 2002) by DGGE analysis of $16 \mathrm{~S}$ rRNA genes. The aim of this work was to try to establish a link between the sensory characteristics of R.D.O. Salers cheese and the microbial dynamics relating to the presence and activity of populations, determined by SSCP analysis (Duthoit et al., 2003). SSCP technique was chosen among other molecular methods (TGGE, DGGE) as it allows the description of the microbial community without culturing the micro-organisms. It has a low detection threshold and high resolution and the DNA samples can be analyzed automatically.

Salers is a semi-hard cheese, produced in the center of France and ripened for at least 3 months. It is made in farms using unrefrigerated raw milk. After milking, the milk is stored in a wooden container, the "gerle", that encourages natural microbial enrichment without use of starter culture.

\section{Materials and methods}

\subsection{Cheeses samples}

The cheese samples used in this study were obtained from three farmers who produce R.D.O. Salers cheese by traditional methods. The cheeses were chosen because of their sensorial diversity. Three cheeses were manufactured on farm A (A1F, $\mathrm{A} 2 \mathrm{~F}$ and $\mathrm{A} 3 \mathrm{~F})$, two on farm $\mathrm{B}(\mathrm{B} 1 \mathrm{~F}$ and $\mathrm{B} 2 \mathrm{~F})$, and two on farm $\mathrm{C}(\mathrm{C} 2 \mathrm{~F}$ and $\mathrm{C} 3 \mathrm{~F})$. Ripening conditions were controlled, at $10{ }^{\circ} \mathrm{C}$ and $96 \%$ humidity. Two other cheeses (B1I and C2I) were made with a pasteurized milk. This milk was inoculated with the microflora of $\mathrm{B} 1 \mathrm{~F}$ or $\mathrm{C} 2 \mathrm{~F}$ milks rejuvenated by microfiltration. These two cheeses, B1I and C2I, were made in an experimental unit with respect to traditional cheesemaking, except that milk was refrigerated after the stay in the wooden container and before the microfiltration.

Samples were taken from the raw milk, during manufacture of the cheese ( 1 day) and ripening $(8,30$, 90 and 150 days), and stored at $-80{ }^{\circ} \mathrm{C}$ for further SSCP analysis.

\section{2. $16 S$ rDNA and $16 S$ rRNA SSCP patterns}

DNA was extracted from the milk and cheese as previously described (Duthoit et al., 2003). RNA was extracted by the same protocol except that phenol at 
$\mathrm{pH} 4.5$ was used, and RNA was purified with RNaid $^{\circledR}$ Kit as specified by the manufacturer (QBIOgene, Montreal, Canada). DNA was amplified as previously described (Duthoit et al., 2003). Subsample of RNA was treated with 9 U of RNase-free DNase (Promega, Madison, WI, USA) $75 \mathrm{~min}$ at 37 ${ }^{\circ} \mathrm{C}$. DNase was then inactivated by heating at $95{ }^{\circ} \mathrm{C}$ for $5 \mathrm{~min}$. The samples were reversely transcribed and amplified in a thermocycler (Applied Biosystems Apllera, Foster City, CA, USA). After an initial denaturation step at $95{ }^{\circ} \mathrm{C}$ for 2 min and an annealing step at $50{ }^{\circ} \mathrm{C}$ for $1 \mathrm{~min}$, the $\mathrm{RT}$ reaction was performed at $68{ }^{\circ} \mathrm{C}$ for $30 \mathrm{~min}$, followed by the same three-stage PCR used for DNA amplification (Duthoit, F., Tessier, L., Montel, M.C., accepted for publication).

SSCP analysis is based on the electrophoretic properties of single-strand DNA in nondenaturing conditions. PCR products were heat-denatured and cooled on ice in order to adopt a single-strand conformation that is sequence-dependant. PCR products, which have a similar size, were separated among their sequence during a capillary electrophoresis and were detected by a laser.

To improve the separation of the numerous sequences, two sets of primers were used, targeting the V3 and V2 variable regions of 16S RNA gene. High GC\% Gram-positive populations were followed with a specific set of primers as described by Duthoit et al., 2003. The primers w34 and w49 targeted the V3 region of the $16 \mathrm{~S}$ rRNA gene, V2F and V2R the V2 region of the $16 \mathrm{~S}$ rRNA gene, and F243 and w34 a part of the 16S rDNA gene of high GC\% Grampositive bacteria (Table 1). Peak identification of SSCP patterns, and analysis of the different profiles have been previously described (Duthoit et al., 2003). Briefly, a 16S rRNA gene clone library was realized from a curd. The V3 and V2 regions of the 16S rRNA gene clone library were analyzed by SSCP, and the resulting peaks were compared to the bacterial pattern of the cheese. Selected clones were then sequenced. Each sequence obtained was compared to sequences available in databases (GenBank and the Ribosomal Database Project [RDP]).

\subsection{Sensory analysis}

At 3 and 5 months of ripening, cheeses were submitted for tasting to 10 trained panelists using a quantitative descriptive analysis. Each sensorial attribute was evaluated on a continuous linear scale ranging from 0 (no perception of the descriptor) to 10 (very intense). The sensory vocabulary used to characterize each cheese comprised 19 terms for flavor, eight for taste, 19 for aroma and seven for texture. The nature of the descriptors was preliminary defined by the trained panelist. Tests were conducted in individual cubicles under red light. All the samples of cheese were coded and presented simultaneously to all panel members in a different order.

\subsection{Statistical analysis}

Principal Component Analysis (PCA) was carried out on sensory as well as microbial variables to represent the structuring of these variables. The first plan (corresponding to the 1 st and 2nd main components) is represented with the amount of total variance explained for each axis. All texture and taste variables were taken into account for PCA. Seventeen flavor variables and 14 aroma variables differentiating cheeses at 3 and 5 months were selected. Variables that showed the lowest scores or that did not discriminate cheeses were eliminated. For each cheese, the microbial data at different times-milk, 1-, 8-, 30-, 90- and 150-day points-were integrated in PCA analysis. The evolution of cheeses according these microbial variables was indicated by

Table 1

PCR primers used in this study

\begin{tabular}{llll}
\hline Primer & Sequence & Target & Reference \\
\hline w34 & TTACCGCGGCGTGCTGGCAC & SSU rRNA bacteria & Zumstein et al., 2000 \\
w49 & ACGGTCCAGACTCCTACGGG & SSU rRNA bacteria & Delbès et al., 1998 \\
F243 & GGATGAGCCCGCGGCCTA & SSU rRNA high GC\% bacteria & Heuer et al., 1997 \\
V2F & GGCGAACGGGTGAGTAA & SSU rRNA bacteria & Duthoit et al., 2003 \\
V2R & ACTGCTGCCTCCCGTAG & SSU rRNA bacteria & Duthoit et al., 2003 \\
\hline
\end{tabular}


an arrow starting from the milk and going towards 150-day point.

To establish relationships between sensory and microbial variables, Partial Least Square (PLS) regression was used. With PLS regression it is possible to construct linear models between a set of predictive variables $X$ and a set of variables to be predicted $Y$ (this set can be reduced to one variable) (Wold et al., 2001). The general principle is to build up the main components on both $X$ and $Y$, with the constraint that the covariance between the main component for $X$ and the main component for $Y$ is maximized. These main components are defined iteratively. Multidimensional PLS regression was not used because, even if it allows the definition of a model for each attribute, the defined model is influenced by the presence of other attributes. The model is therefore difficult to interpret, especially when the attributes to be predicted are not very much correlated.

Sensory variables were measured by a jury composed of 10 panelists. In order to exploit this information as fully as possible, we used PLS regression on the marks given by each panelist.

All statistical analyses were performed using $\mathrm{R}^{(\mathcal{C}}$ (2003), available at http://www.r-project.org.

\section{Results}

\subsection{Sensory analysis}

Fig. 1 shows the evolution of each cheese from 3 months to 5 months in the first plan resulting from the PCA applied to the texture (Fig. 1A), taste (Fig. 1B), aroma (Fig. 1C) and flavor (Fig. 1D) variable scores.

On the basis of texture descriptors, cheeses were not grouped according to the farm origin or according to the manufacturing process (farm or experimental unit) as shown in Fig. 1A. The first axis distinguished between firm and granular texture on one hand (negative correlations), and oiliness, sticky, melting and elastic on the other hand. Cheeses were differentiated according to their time of ripening. Fivemonth cheeses melted more easily and were less elastic than 3-month cheeses. Cheese A3F was an exception as it was more elastic, oilier and stickier at 5 months. Taking into account taste descriptors, all the cheeses became more persistent, less acid and less pungent at 5 months (Fig. 1B). Whatever the ripening time, cheese $\mathrm{A} 2 \mathrm{~F}$ was the sweetest whereas cheese $\mathrm{C} 2 \mathrm{~F}$ was the most astringent, the most bitter and the most metallic. Considering aroma descriptors, cheeses evolved in the same way between 3 and 5 months (Fig. 1C). Apart from cheeses A3F, cheeses at 5 months were more caramel, meaty, rancid and less citrus fruit, spiced and vanilla. The most important change was noticed for cheeses B1F and B1I. However, B1F was the most vanilla and caramel, and B1I was the most fermented cream, pepper, cow shed, and spiced. Cheeses from different origins were differentiated by flavor descriptors (Fig. 1D). Cheeses $\mathrm{C} 2 \mathrm{~F}, \mathrm{C} 3 \mathrm{~F}$ and $\mathrm{C} 2 \mathrm{I}$ were grouped according to their fermented cream, chemical, spiced, garlic flavors (Fig. 1D). On the contrary, A1F, A2F and A3F were more characterized by cream, vanilla, butter and caramel. The intensity of hazelnut, garlic flavors decreased between 3 and 5 months for all cheeses except B1I, while caramel, fermented grass, walnut, rancid and butter flavors increased.

\subsection{Microbial analysis}

Microbial data were generated by SSCP analysis of DNA (presence of the microorganism) and RNA (activity of the microorganism) directly extracted from milk and cheeses. For each set of primers, the community was represented by an electrophoregram where each peak corresponds to one or several sequences of bacteria (see Fig. 2 as an example). Most of the peaks were identified and related to a microorganism sequence, some peaks corresponding to the co-elution of different sequences, whereas others remained unidentified (Duthoit et al., 2003). The ratio of each peak on each profile (area of the peak/sum of the areas of all the peaks of the profile) was calculated. These ratios were integrated into PCA and PLS regression analyses.

Fig. 3 shows the evolution of microbial data for each cheese in the first plan resulting from the PCA applied to the ratios derived from DNA and RNA SSCP analysis. Milk, 1-, 8-, 30-, 90- and 150-day points were represented and linked for each cheese by an arrow pointing at the 150-day point.

On PCA calculated with the ratios from DNA SSCP patterns (Fig. 3A), the milks B1I and C2I distinguished from the other milks by their high ratio 
A

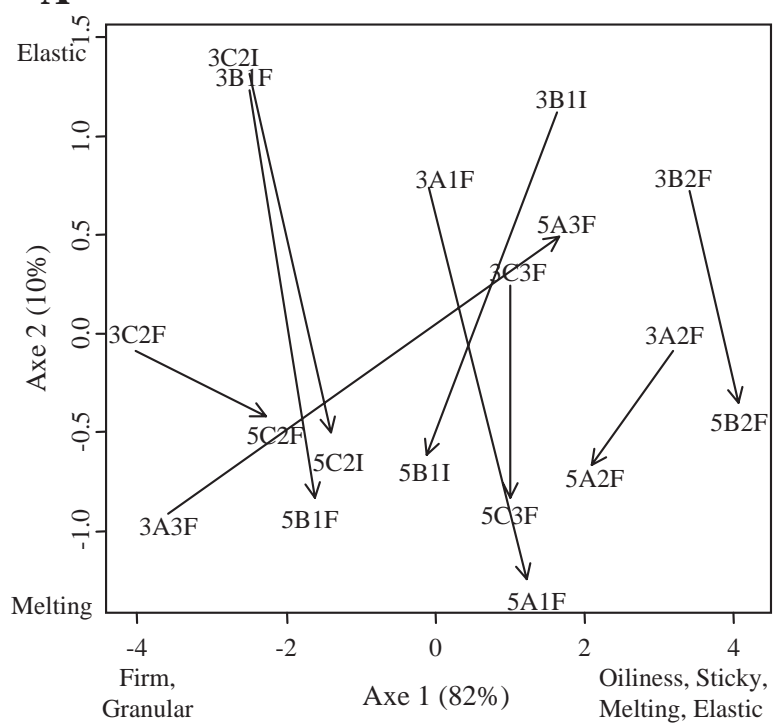

C

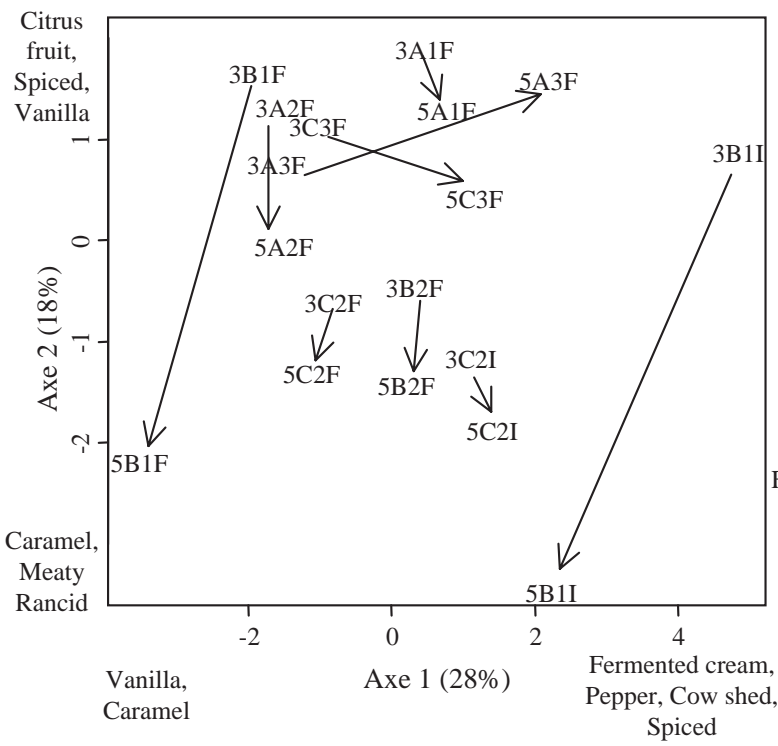

B

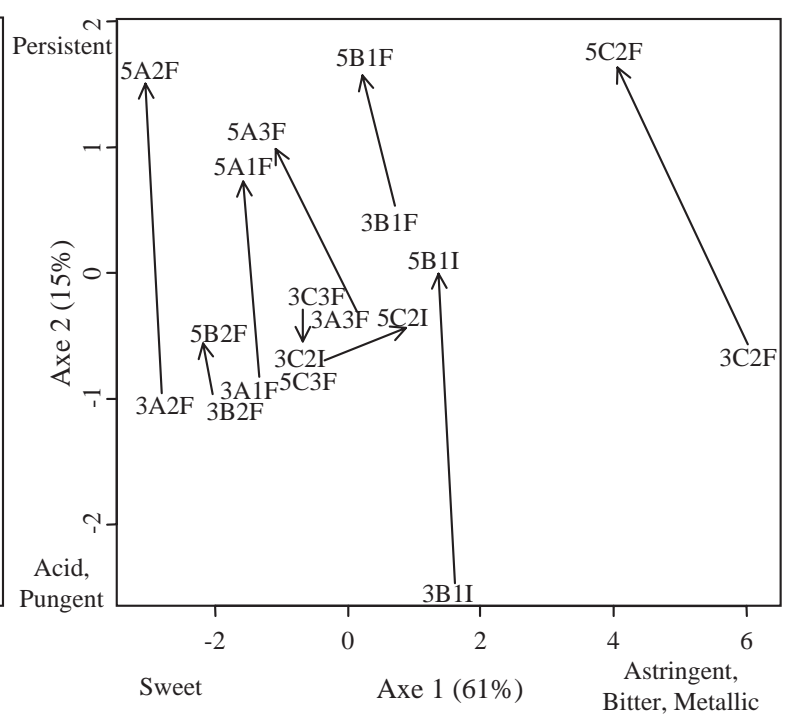

D

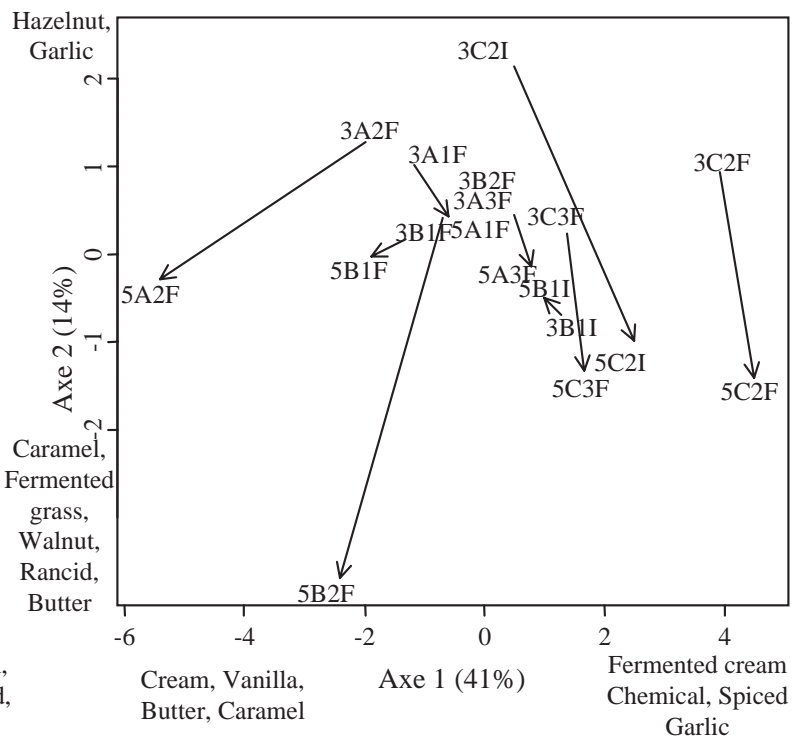

Fig. 1. Principal Component Analyses of the sensory variable scores: plot of main axes 1 and 2. 3- and 5-month points were represented. A: texture descriptors. B: taste descriptors. C: aroma descriptors. D: flavor descriptors. 3 and 5 before the name of the cheese signify 3 months and 5 months of ripening.

of Enterobacteriaceae. The farm milks have a higher ratio of the SSCP peak corresponding to Bifidobacterium group sequence. For all cheeses, the most important changes were noticed during the first day with an increase of lactic acid bacteria populations. During ripening all cheeses manufactured on the farms (A1F, A2F, A3F, B1F, C2F, C3F) were grouped on the left-hand side of the PCA. For all these cheeses the balance between the different bacteria flora changed during ripening as the ratio of the peak corresponding to lactic acid bacteria sequences (Lactococcus lactis, Streptococcus thermophilus, Lac- 


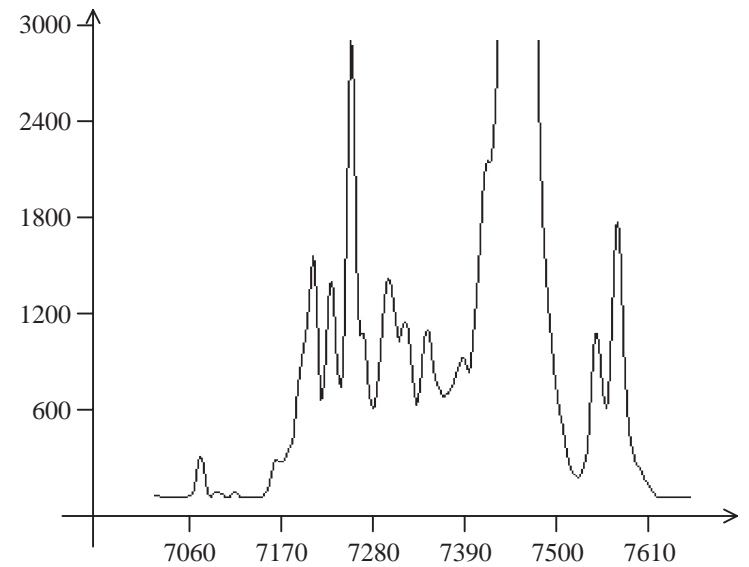

Fig. 2. V3 SSCP patterns of PCR-amplified 16S rRNA fragments from bacterial communities of a 1-day farm cheese. $y$-axis: fluorescence, $x$-axis, elutions in scans (unit if the analysis software).

tobacillus pentosus, Lactobacillus plantarum) and of the peak corresponding to Corynebacterium afermentans sequence increased. Between 3 and 5 months (90 and 150 days), there was little evolution for cheeses A1F, A2F, A3F and C3F. However, each cheese had its own dynamics. The two cheeses manufactured in the experimental unit (B1I and C2I) were also well differentiated and characterized by a higher proportion of Enterobacteriaceae, Citrobacter sp. and Bacillus sp. Cheese B2F was closer to B1I than to those manufactured on the other farms.

Milks were grouped on PCA calculated with ratios from RNA SSCP patterns (Fig. 3B). They were characterized by a high ratio of Streptococcus dysagalactiae, Leuconostoc sp. and Propionibacterium freundenreichii populations. The cheeses were more dispersed on RNA PCA than on DNA PCA. For each cheese, there were important changes from one time to another time. The two cheeses manufactured in the experimental unit were differentiated by an important ratio of Enterobacteriaceae and more Citrobacter sp. populations, but each cheese had its own dynamics.

\subsection{Relationships between sensorial characteristics and microbial data}

Relationships between the sensory descriptors and the microbiological data were studied using PLS regression. The 25 variables that best predicted each of the descriptors were taken into account for the interpretation.

Texture, aroma, flavor and taste variables, which variance can be explained by microbial data at more than $15 \%$, are shown in Table 2. The percentage of variances explained ranged from $15 \%$ to $54 \%$. The number of variables explained was smaller at 3 months than at 5 months but the percentage of variance explained was lower at 5 months than at 3 months. At 5 months, more aroma, taste and flavor variable variances could be explained by microbiological data at values above $15 \%$. Variance of texture and taste descriptors was better explained than that of flavor or aroma descriptors.

Some correlations were made between sensorial variables and microbiological data as shown in Table 3. In this table are indicated the total numbers of DNA and RNA ratio peaks with their origin (peaks from SSCP patterns of milk, 1-, 8-, 30-, 90- or 150-day cheeses) which contribute to the explanation of sensorial variables. The number of DNA peaks that explained variation was generally higher than the number of RNA peaks for texture descriptors, while it was the inverse for aroma and flavor descriptors, except "butter" taste and "citrus fruit" aroma. The microbial peaks that explained the variables were distributed uniformly from 0 to 150 days for "sticky" texture, "granular", "chemical" taste, "sweet", and "citrus fruit" aroma. For "firmness", "friability", "burnt", "bitterness", "salty", the number of peaks that explained the variance increased until 8 or 30 days and then decreased. The number of peaks connected to the "metallic" and "spiced" descriptors tended to be more important at 90 and 150 days. Peaks that explained the other variables were irregularly distributed from 0 to 150 days.

The PLS analysis establishes a relationship between the sensorial variable and the microbiological data. Correlations are not necessarily causally related. The link between the sensorial variable score and the ratio of a peak does not mean that the peak is involved in the elaboration of the sensorial variable. The resulting correlations were rather complex as shown as an example for oiliness and bitterness in Table 4. A sensorial variable was always explained by numerous peaks present on SSCP patterns at one or different times. SSCP peaks ratios that explained the sensory variables were derived from RNA and 
A

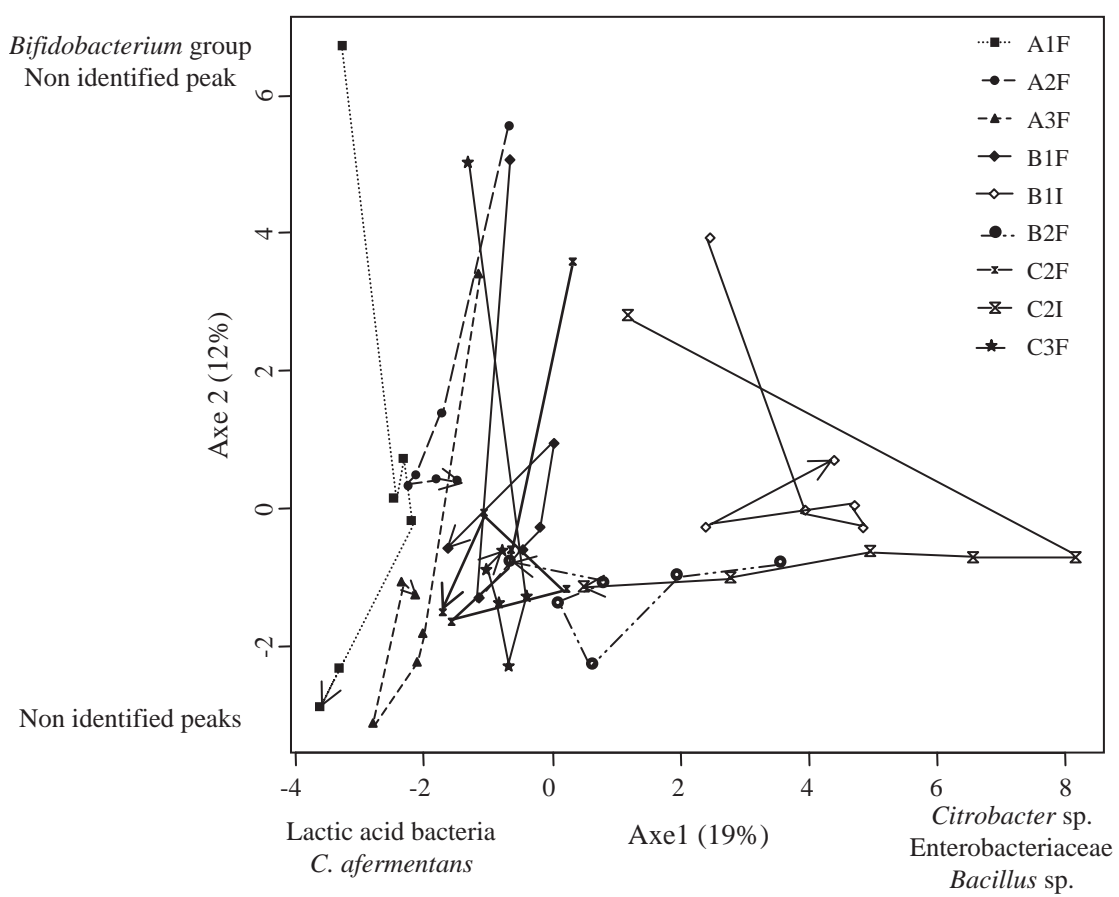

B

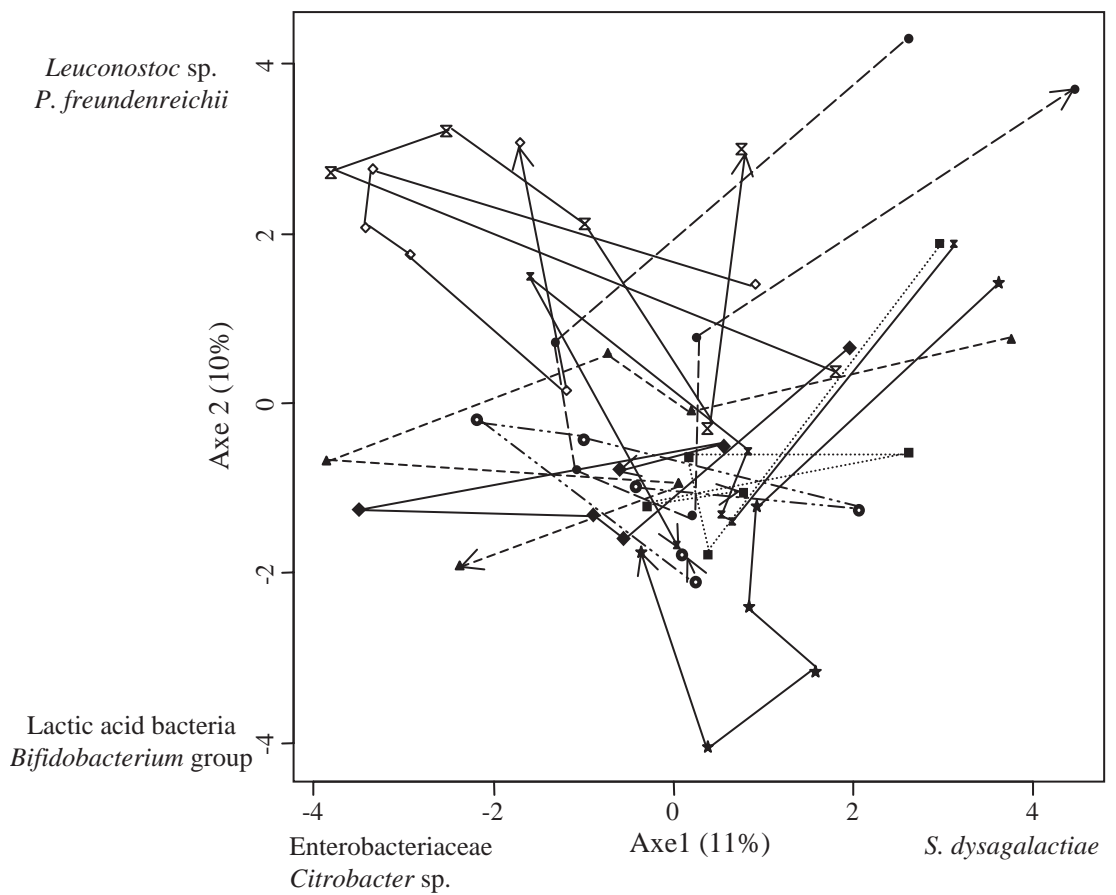

Fig. 3. Principal Component Analyses of the microbial SSCP analysis data: plot of principal axes 1 and 2. Milk, 1-, 8-, 30-, 90- and 150-day points were represented and linked for each cheese by an arrow pointing at the 150-day point. A: DNA SSCP analysis data; B: RNA SSCP analysis data. 
Table 2

Percentage of variance (\%) for texture, taste, aroma and flavor attributes explained by microbial data

\begin{tabular}{|c|c|c|c|c|c|}
\hline \multirow[t]{2}{*}{ Attributes } & \multicolumn{2}{|c|}{ Variance $(\%)$} & \multirow[t]{2}{*}{ Attributes } & \multicolumn{2}{|c|}{ Variance $(\%)$} \\
\hline & 3 months & 5 months & & 3 months & 5 months \\
\hline Oily (Tx) & 54 & 45 & Bitter (Ta) & 43 & 27 \\
\hline Stick (Tx) & 46 & 35 & Salt (Ta) & 30 & \\
\hline Melting (Tx) & 46 & 21 & Roasted onion (A) & & 23 \\
\hline Granular (Tx) & 46 & 35 & Butter (F) & & 19 \\
\hline Friable (Tx) & 43 & 27 & Citrus fruit (A) & & 19 \\
\hline Firm (Tx) & 31 & 22 & Sweet $(F)$ & & 18 \\
\hline \multirow[t]{6}{*}{ Elastic (Tx) } & 23 & 19 & Burnt (F) & & 17 \\
\hline & & & Spiced (F) & & 16 \\
\hline & & & Chemical (F) & & 16 \\
\hline & & & Vanilla (F) & & 15 \\
\hline & & & Metallic (Ta) & & 15 \\
\hline & & & Rancid (F) & & 14 \\
\hline
\end{tabular}

(Tx): texture, $(\mathrm{Ta})$ : taste, $(\mathrm{A})$ : aroma, $(\mathrm{F})$ : Flavor.

Variance (\%) means percentage of attributes explained by microbial data; the microbial data taken into account corresponded to peaks on DNA or RNA SSCP profiles.

Table 3

Number of peaks derived (i) from DNA or RNA SSCP analysis, and (ii) from milk, 1-, 8-, 30-, 90- and 150-day SSCP patterns, contributing to the explanation of sensorial variables

\begin{tabular}{|c|c|c|c|c|c|c|c|c|c|}
\hline \multirow[t]{2}{*}{ Variable } & \multirow[t]{2}{*}{ Ripening time } & \multicolumn{2}{|c|}{ Number of: } & \multicolumn{6}{|c|}{ Number of peaks from SSCP patterns at: } \\
\hline & & $\begin{array}{l}\text { DNA } \\
\text { peaks }\end{array}$ & $\begin{array}{l}\text { RNA } \\
\text { peaks }\end{array}$ & $\begin{array}{l}0 \text { day } \\
\text { (milk) }\end{array}$ & 1 day & 8 days & 30 days & $\begin{array}{l}90 \text { days } \\
3 \text { months }\end{array}$ & $\begin{array}{l}150 \text { days } \\
5 \text { months }\end{array}$ \\
\hline \multirow[t]{2}{*}{ Oiliness (Tx) } & 3 & 14 & 11 & 3 & 5 & 6 & 3 & 8 & 0 \\
\hline & 5 & 15 & 10 & 2 & 4 & 5 & 1 & 7 & 6 \\
\hline \multirow{2}{*}{ Sticky $(\mathrm{Tx})$} & 3 & 13 & 12 & 4 & 6 & 5 & 3 & 7 & 0 \\
\hline & 5 & 13 & 12 & 4 & 4 & 3 & 4 & 5 & 5 \\
\hline \multirow[t]{2}{*}{ Melting (Tx) } & 3 & 17 & 8 & 5 & 1 & 8 & 6 & 5 & 0 \\
\hline & 5 & 14 & 11 & 3 & 2 & 8 & 2 & 6 & 4 \\
\hline \multirow[t]{2}{*}{ Micro-structure (Tx) } & 3 & 15 & 10 & 4 & 6 & 4 & 6 & 5 & 0 \\
\hline & 5 & 15 & 10 & 3 & 3 & 4 & 2 & 8 & 5 \\
\hline \multirow[t]{2}{*}{ Friability $(\mathrm{Tx})$} & 3 & 18 & 7 & 1 & 4 & 9 & 7 & 4 & 0 \\
\hline & 5 & 15 & 10 & 2 & 0 & 7 & 8 & 4 & 4 \\
\hline \multirow[t]{2}{*}{ Firmness (Tx) } & 3 & 13 & 12 & 4 & 4 & 8 & 5 & 4 & 0 \\
\hline & 5 & 16 & 9 & 1 & 2 & 6 & 4 & 7 & 5 \\
\hline \multirow[t]{2}{*}{ Elasticity (Tx) } & 3 & 16 & 9 & 2 & 4 & 8 & 4 & 7 & 0 \\
\hline & 5 & 16 & 9 & 5 & 2 & 2 & 4 & 7 & 5 \\
\hline \multirow[t]{2}{*}{ Bitterness (Ta) } & 3 & 11 & 14 & 3 & 4 & 6 & 8 & 4 & 0 \\
\hline & 5 & 10 & 15 & 1 & 7 & 5 & 5 & 3 & 4 \\
\hline Salty (Ta) & 3 & 7 & 18 & 4 & 2 & 11 & 6 & 2 & 0 \\
\hline Roasted onion (A) & 5 & 11 & 14 & 4 & 6 & 1 & 5 & 3 & 6 \\
\hline Butter $(\mathrm{F})$ & 5 & 17 & 8 & 2 & 5 & 5 & 2 & 3 & 8 \\
\hline Citrus fruit (A) & 5 & 17 & 8 & 4 & 5 & 5 & 2 & 6 & 3 \\
\hline Sweet (F) & 5 & 11 & 14 & 2 & 6 & 6 & 3 & 5 & 3 \\
\hline Burnt (F) & 5 & 9 & 16 & 1 & 6 & 6 & 6 & 4 & 2 \\
\hline Spiced $(F)$ & 5 & 11 & 14 & 3 & 3 & 4 & 3 & 5 & 7 \\
\hline Chemical (F) & 5 & 12 & 13 & 3 & 6 & 4 & 4 & 5 & 3 \\
\hline Vanilla $(\mathrm{F})$ & 5 & 12 & 13 & 4 & 6 & 5 & 2 & 2 & 6 \\
\hline Metallic (Ta) & 5 & 13 & 12 & 5 & 2 & 5 & 7 & 3 & 9 \\
\hline Rancid (F) & 5 & 9 & 16 & 4 & 6 & 2 & 6 & 2 & 5 \\
\hline
\end{tabular}

$(\mathrm{Tx})$ : texture, $(\mathrm{Ta})$ : taste, $(\mathrm{A})$ : aroma, $(\mathrm{F})$ : flavor. 
Table 4

Prediction of sensorial descriptors of cheese on basis of their bacterial dynamics by PLS regression

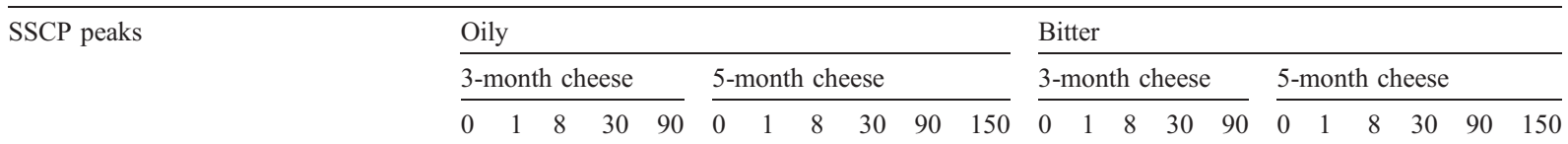

From DNA patterns

Lb. pentosus/Ln. pseudomesenteroides

Lb. pentosus

S. thermophilus/

Ln. mesenteroides

E. faecium/Enterobacteriaceae

Citrobacter $\mathrm{sp}$.

Ln. pseudomesenteroides

NI peak 01

Bacillus sp./E. faecium

Enterobacteriaceae

NI peak 11

NI peak 14

Lb. plantarum

NI peak 12

S. thermophilus

NI peak 07

Bacillus sp.

NI peak 09

\section{From RNA patterns}

Ln. pseudomesenteroides

NI peak 01

NI peak 14

NI peak 27

Lc. lactis

Lb. pentosus/

Ln. pseudomesenteroides

Enterobacteriaceae

B. nesterenkovii

Bacillus sp.

NI peak 21

S. thermophilus

C. bovis

Brevibacterium sp.

Citrobacter

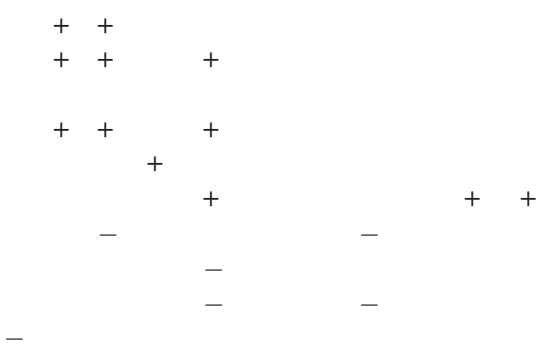

E. faecium

The data of bacterial dynamics were the DNA (presence of bacterial species) and RNA (activity of bacterial species) ratio peaks at different times of ripening.

/: separate two sequences that co-eluted on SSCP patterns.

+ : positive correlation, - : negative correlation.

DNA: peak from DNA analysis, RNA: peak from RNA analysis.

0 (milk), 1, 8, 30, 90, 150: time in days.

Lb.: Lactobacillus, Ln.: Leuconostoc, S.: Streptococcus, B.: Brachybacterium, C.: Corynebacterium, E.: Enterococcus, Lc.: Lactococcus. NI: non-identified.

DNA SSCP patterns. For example, 17 different SSCP peaks ( 9 from DNA SSCP patterns and 8 from RNA SSCP patterns) were involved in the explanation of the texture descriptor "oily" for the 3-month cheese, and 18 peaks ( 9 from DNA SSCP patterns and 9 from RNA SSCP patterns) for the 5-month cheese. For the taste descriptor "bitter", eight different SSCP peaks (three from DNA SSCP patterns and five from RNA 
SSCP patterns) were involved for the 3-month cheeses and eight (four from DNA SSCP patterns and four from RNA SSCP patterns) involved for the 5 -month cheeses. SSCP peaks involved in the explanation of a sensorial variable at 3 months were also involved in the explanation of the sensorial variable at 5 months. For example, the peaks corresponding to Ln. pseudomesenteroides, Lc. lactis, the non-identified peaks $(01,14,27)$ were involved in the explanation of the texture descriptor "oily" at 3 and 5 months, as were the peaks corresponding to Bacillus sp., Enterobacteriaceae, or E. faecium for the taste descriptor "bitter". Some peaks seem to be involved at the beginning of the ripening (like the ratios of $L b$. pentosus/Ln. pseudomesenteroides peak ratios correlated to "oiliness"). Other peaks may be involved at the end of the ripening, as Citrobacter sp. peak correlated to "oily" texture, or all over the fabrication and the ripening, as the peak corresponding to Enterobacteriaceae sequences which was correlated to the "bitter" taste.

\section{Discussion}

The sensory analysis of R.D.O. Salers cheeses revealed a high diversity in their sensorial characteristics that changed between 3 and 5 months. It seems that a global view of the dynamics of the bacterial community, as obtained by SSCP DNA and RNA analysis, was relevant in explaining sensorial variance. Indeed, bacteria that are not considered as bacteria of technological interest in cheese core, such as high GC\% Gram-positive bacteria, Enterobacteriaceae, Bacillus sp., and also unidentified peaks of SSCP patterns were shown to be involved with the elaboration of texture, taste, flavor or aroma. The study underlines the relevance of measuring the global activity of the bacterial communities. The changes in the sensorial properties between 90 and 150 days seem to be due in part to RNA profile changes. Few studies deal with relationships between microbial composition and sensorial qualities. Microbiological description is rarely global. The same bacterial species may have the opposite effect on the sensory characteristics. In Cheddar, the level of hydrophobic peptides (responsible for bitterness) decreased when there was an increase in the amount of $E$. faecalis added (Lane et al., 1996). The level of Enterococcus was also negatively correlated with bitterness in Swiss-type cheese (Beuvier et al., 1997). These bacteria are proteolytic, and they were positively correlated to bitterness in Cebreiro cheese (Centeno et al., 1999).

However, the global view of bacterial communities obtained from this study does not provide enough information to explain all the sensorial qualities of R.D.O. Salers cheese. Intra-species diversity, global and specific metabolic activity at a strain level, and the characteristics of the raw material may also contribute to the variability. The genomic diversity of lactic acid bacteria in these R.D.O. Salers cheeses was highlighted by Callon (Callon et al., 2004). It may be associated with the variability of their biochemical properties. Peptidase activity of $S$. thermophilus, esterolytic and lipolytic activities of lactic acid bacteria vary among strains (Giraffa et al., 2001; Katz et al., 2002). Flavoring properties of lactic acid bacteria estimated by the production of neutral volatile compounds have been shown to be strainspecific (Mauriello et al., 2001). Today, there is no valid method to measure the specific expression of all the microorganisms in cheeses. It would be interesting to integrate yeast SSCP profiles into microbiological data. The characteristics of the milk also play an important role in the elaboration of the sensorial qualities. Saint-Nectaire cheeses manufactured with milk from grass-fed cows present higher scores for flavor and aroma intensities than cheeses manufactured with milk from silage- or hay-fed cows (Coulon and Priolo, 2002). In order to comply with specifications for the production of R.D.O. Salers cheese the milk used must come from grazing cows. In our study, the three farms were in a restricted geographic zone and were studied in the same month of June. At this period of the year, the effect of feeding animals was minimal.

Our study underlines the relevance of considering cheeses like a real ecosystem in which one microorganisms interact each other with the matrix. The two cheeses manufactured with the same microflora (raw milk or microfiltration retentate in pasteurized milk) differed depending on their microbial dynamics or their sensorial qualities. The microbial differences observed between raw milk and reconstituted milk show the difficulty in collecting all the microflora by microfiltration. The changes in sensorial 
qualities could also be attributed to the modification of raw material by thermal treatment (Grappin and Beuvier, 1997).

This study shows that sensorial qualities of raw milk cheeses are not easily interpretable. In the future, a more integrated approach including the biochemical composition of raw material (volatile and nonvolatile compounds), the physico-chemical parameters (temperature, humidity, oxygen, etc.), the structure, the general activity and the specific activities of microbial community should be developed. In that case statistical constraints will mean that a high number of individuals will need to be studied. This should be overcome by continuing to develop global, rapid methods to measure genomic microbial diversity and specific activities, but also aromatic compound diversity.

\section{Acknowledgments}

F. Duthoit was supported by an INRA-Region Auvergne thesis grant. We thank the "Comité Interprofessionnel des Fromages" for their interest in this work.

\section{References}

Ampe, F., Sirvent, A., Zakhia, N., 2001. Dynamics of the microbial community responsible for traditional sour cassava starch fermentation studied by denaturing gradient gel electrophoresis and quantitative rRNA hybridization. International Journal of Food Microbiology 65, 45-54.

Ayad, E.H.E., Verheul, A., de Jong, C., Wouters, J.T.M., Smit, G., 1999. Flavour forming abilities and amino acid requirements of Lactococcus lactis strains isolated from artisanal and non-dairy origin. International Dairy Journal 9, 725-735.

Ben Lawlor, J., Delahunty, C.M., Wilkinson, M.G., Sheehan, J., 2001. Relationships between the sensory characteristics, neutral volatile composition and gross composition of ten cheese varieties. Lait 81, 487-507.

Bérodier, F., Stévenot, C., Schlich, P., 1997. Descripteurs de l'Arôme du Fromage de Comté. Lebensmittel Wissenschaft und Technologie 30, 298-304.

Beuvier, E., Berthaud, K., Cegarra, S., Dasen, A., Pochet, S., Buchin, S., Duboz, G., 1997. Ripening and quality of Swisstype cheese made from raw, pasteurized or microfiltered milk. International Dairy Journal 7, 311-323.

Buchin, S., Delague, V., Duboz, G., Berdagué, J.L., Beuvier, E., Pochet, S., Grappin, R., 1998. Influence of pasteurization and fat composition of milk on the volatile compounds and flavor characteristics of a semi-hard cheese. Journal of Dairy Science 81, 3097-3108.

Callon, C., Millet, L., Montel, M.C., 2004. Diversity of lactic acid bacteria isolated from AOC Salers cheese. Journal of Dairy Research 71, 231-244.

Centeno, J.A., Menendez, S., Hermida, Ma., Rodriguez-Otero, J.L., 1999. Effects of addition of Enterococcus faecalis in Cebreiro cheese manufacture. International Journal of Food Microbiology 48, 97-111.

Cocolin, L., Manzano, M., Cantoni, C., Comi, G., 2001. Denaturing gradient gel electrophoresis analysis of the 16S rRNA gene V1 region to monitor dynamic changes in the bacterial population during fermentation of Italian sausages. Applied and Environmental Microbiology 67, 5113-5121.

Coulon, J.B., Priolo, A., 2002. La qualité sensorielle des produits laitiers et de la viande dépend des fourrages consommés par les animaux. Productions Animales 15, 333-342.

Curioni, P.M.G., Bosset, J.O., 2002. Key odorants in various cheese types as determined by gas chromatography-olfactometry. International Dairy Journal 12, 959-984.

Delbès, C., Godon, J.J., Moletta, R., 1998. 16S rDNA sequence diversity of a culture-accessible part of an anaerobic digestor bacterial community. Environmental Microbiology 4, 267-275.

Duthoit, F., Godon, J.J., Montel, M.C., 2003. Bacterial community dynamics during production of Registered Designation of Origin Salers cheese as evaluated by 16S rRNA gene Single Strand Conformation Polymorphism analysis. Applied and Environmental Microbiology 69, 3840-3848.

Giraffa, G., Paris, A., Valcavi, L., Gatti, M., Neviani, E., 2001. Genotypic and phenotypic heterogeneity of Streptococcus thermophilus strains isolated from dairy products. Journal of Applied Microbiology 91, 937-943.

Grappin, R., Beuvier, E., 1997. Possible implications of milk pasteurization on the manufacture and sensory quality of ripened cheese. International Dairy Journal 7, 751-761.

Heuer, H., Kresk, M., Baker, P., Smalla, K., Wellington, E.M.H., 1997. Analysis of actinomycete communities by specific amplification of genes encoding 16S rRNA and gel-electrophoretic separation in denaturing gradients. Applied and Environmental Microbiology 63, 3233-3241.

Katz, M., Median, R., Gonzalez, S., Oliver, G., 2002. Esterolytic and lipolytic activities of lactic acid bacteria isolated from ewe's milk cheese. Journal of Food Protection 65, 1997-2001.

Lane, C.N., Fox, P.F., 1996. Contribution of starter and adjunct Lactobacilli to proteolysis in Cheddar cheese during ripening. International Dairy Journal 6, 715-728.

Lavanchy, P., Berodier, F., Zannoni, M., Noel, Y., Adamo, C., Squella, J., Herrero, L., 1993. Sensory evaluation of the texture of hard and semi-hard cheeses. A collaborative study. Lebensmittel-Wissenschaft and Technologie 26, 59-68.

Lee, D.H., Zo, Y.G., Kim, S.J., 1996. Nonradioactive method to study genetic profiles of natural bacterial communities by PCRsingle-strand-conformation polymorphism. Applied and Environmental Microbiology 62, 3112-3120.

Liu, W.T., Marsh, T.L., Cheng, H., Forney, L.J., 1997. Characterization of microbial diversity by determining terminal restriction 
fragment length polymorphisms of genes encoding 16S rRNA. Applied and Environmental Microbiology 63, 4516-4522.

Mauriello, G., Moio, L., Moschetti, G., Piombino, P., Addeo, F., Coppola, S., 2001. Characterization of lactic acid bacteria strains on the basis of neutral volatile compounds produced in whey. Journal of Applied Microbiology 90, 928-942.

Menendez, S., Centeno, J.A., Godinez, R., Rodriguez-Otero, J.L., 2000. Effects of Lactobacillus strains on the ripening and organoleptic characteristics of Arzua-Ulloa cheese. International Journal of Food Microbiology 59, 37-46.

Muyzer, G., Smalla, K., 1998. Application of denaturing gradient gel electrophoresis (DGGE) and temperature gradient gel electrophoresis (TGGE) in microbial ecology. Antonie Van Leeuwenhoek 73, 127-141.

Randazzo, C.L., Torriani, S., Akkermans, A.D.L., de Vos, W.M., Vaughan, E.E., 2002. Diversity, dynamics, and activity of bacterial communities during production of an artisanal Sicilian cheese as evaluated by $16 \mathrm{~S}$ rRNA analysis. Applied and Environmental Microbiology 68, 1882-1892.

Rychlik, M., Bosset, J.O., 2001. Flavour and off-flavour compounds of Swiss Gruyère cheese. Evaluation of potent odorants. International Dairy Journal 11, 895-901.
Sarantinopoulos, P., Kalantzopoulos, G., Tsakalidou, E., 2002. Effect of Enterococcus faecium on microbiological, physicochemical and sensory characteristics of Greek Feta cheese. International Journal of Food Microbiology 76, 93-105.

Spinnler, H.E., Berger, C., Lapadatescu, C., Bonnarme, P., 2001. Production of sulfur compounds by several yeasts of technological interest for cheese ripening. International Dairy Journal 11, 245-252.

van Beek, S., Priest, F.G., 2002. Evolution of the Lactic Acid Bacterial community during malt Whisky fermentation: a polyphasic study. Applied and Environmental Microbiology 68, 297-305.

Wold, S., Sjostrom, M., Eriksson, L., 2001. PLS-regression: a basic tool of chemometrics. Chemometric and Intelligence Laboratory Systems 58, 109-130.

Zumstein, E., Moletta, R., Godon, J.J., 2000. Examination of two years of community dynamics in an anaerobic bioreactor using fluorescence polymerase chain reaction (PCR) Single-Strand Conformation Polymorphism Analysis. Environmental Microbiology 2, 69-78. 